\title{
Hyboscolex sp.: the first find of the family Scalibregmatidae (Annelida) in the Black Sea
}

\author{
E.V. Lisitskaya ${ }^{1}$, N.A. Boltachova, A.A. Nadolny
}

The A.O. Kovalevsky Institute of Marine Biological Research (IMBR) of Russian Academy of Sciences, 2 Nakhimovav., Sevastopol, Crimea 299011 Russia. E-mail: nboltacheva@mail.ru, nadolnyanton@mail.ru

${ }^{1}$ Corresponding author.E-mail: e.lisitskaya@gmail.com

ABSTRACT. The fauna of polychaetes of the Black Sea has been studied in detail, but species of the Scalibregmatidae family have never been indicated in literature to date. Scalibregmatids are wide spread in the World Ocean, but they are rarely found in benthic collections. In 2017, in one of the bays of Sevastopol (Crimea), a member of Scalibregmatidae, Hyboscolex sp., was first identified. The sediment at the collection site is mediumgrained sand of crushed mollusk shells with a small admixture of crushed limestone. The depth was $15 \mathrm{~m}$. The temperature of water was $19.3^{\circ} \mathrm{C}$ and the salinity was $17.7 \%$. The article presents morphological characteristics and photographs of alive and fixed in $4 \%$ formaldehyde specimen. Species affiliation Hyboscolex sp. which was found in the Black Sea is under discussion.

How to cite this article: Lisitskaya E.V., Boltachova N.A., Nadolny A.A. 2019. Hyboscolex sp.: the first find of the family Scalibregmatidae (Annelida) in the Black Sea // Invert. Zool. Vol.16 No.3. P.226-232. doi: 10.15298/invertzool.16.3.03

KEY WORDS: Polychaeta, Scalibregmatidae, Hyboscolex sp., the Black Sea.

\section{Hyboscolex sp. - первая находка семейства Scalibregmatidae (Annelida) в Черном море}

\section{Е.В. Лисицкая', Н.А. Болтачева, А.А. Надольный}

Институт морских биологических исследований им. А.О. Ковалевского РАН, проспект Нахимова, 2, Севастополь, Крым 299011, Россия.

E-mail:nboltacheva@mail.ru,nadolnyanton@mail.ru

${ }^{1}$ Автор для переписки. E-mail: e.lisitskaya@gmail.com

РЕЗЮМЕ: Фауна полихет Черного моря изучена детально, однако, представители семейства Scalibregmatidae до настоящего времени не указаны. Скалибрегматиды распространены в Мировом океане, но в бентосных сборах попадаются редко. В 2017 г. в Черном море в одной из бухт Севастополя впервые обнаружен представитель семейства Scalibregmatidae - Hyboscolex sp. Грунт в месте сбора - средний песок из измельчённых раковин моллюсков с небольшой примесью раздробленной известняковой породы, глубина 15 м. Температура воды составляла $19,3^{\circ} \mathrm{C}$, соленость - 17,7\%о. В статье представлена морфологическая характеристика и фотографии живого экземпляра и после фиксации 4\%-ным раствором формальдегида. Обсуждается видовая принадлежность найденного Hyboscolex sp. 
Как цитировать эту статью: Lisitskaya E.V., Boltachova N.A., Nadolny A.A. 2019. Hyboscolex sp.: the first find of the family Scalibregmatidae (Annelida) in the Black Sea // Invert. Zool. Vol.16 No.3. P.226-232. doi: 10.15298/invertzool.16.3.03

КЛЮЧЕВЫЕ СЛОВА: Polychaeta, Scalibregmatidae, Hyboscolex sp., Черное море.

\section{Introduction}

The fauna of polychaetes of the Black Sea has been studied well enough, but the species of the Scalibregmatidae family have never been mentioned to date (Kisseleva, 2004; Kurt ahin, Çýnar, 2012). Scalibregmatids are wide spread in the World Ocean. These are burrowing infauna deposit feeding worms. They are found starting from the intertidal areas to deep water, but the most species inhabit depths of more than 1000m (Bakken et al., 2014; Blake, 2015). For this reason, information on the biology of polychaetes of Scalibregmatidae is extremely scarce. It is known that they prefer to dwell on silty seabed. When burrowing the bottom sediment, they use the frontal horns (Elder, 1973), as shown for Polyphysia crassa (Örsted, 1844), and they do not build tubes. For some species, there is evidence that they rise into the water column during spawning, breed in the first year of life and live at least two years (Blake, 2015; Pamungkas, 2015). There is little information available regarding the larval development of scalibregmatids.

In the Black Sea, we found a member of Scalibregmatidae for the first time in one of the bays of Sevastopol. The aim of this work is to present the data on the first discovery of $\mathrm{Hy}$ boscolex sp. in the Azov-Black Sea basin.

\section{Materials and Methods}

In September 2017, in Kruglaya Bay (southwestern part of Crimea), live polychaetes of different species were collected for further study in the laboratory. The gathering took place at the entrance to the bay $\left(44^{\circ} 36^{\prime} 29.6^{\prime \prime} \mathrm{N}, 33^{\circ} 26^{\prime}\right.$ $32.3^{\prime \prime} \mathrm{E}$ ) as deep as $15 \mathrm{~m}$. The bottom sediment at the collection site is medium-grained sand of crushed mollusk shells with a small admixture of crushed limestone. The temperature of water at the time of gathering was $19.3^{\circ} \mathrm{C}$ and the salinity amounted to $17.7 \%$. In the collections, polychaetes Lindrilus flavocapitatus (Uljanin, 1877), Protodorvillea kefersteini (McIntosh, 1869) were present, as well as an initially unidentified polychaete species. The polychaetes were kept in an aquarium with sea water and fed with a mixture of microalgae (Isochrysis galbana Parke, Tetraselmis suecica Butch., Phaeodactylum tricornutum Bohl., Rhodomonas salina Wisl.). In January 2018, an unidentified polychaete was photographed and fixed with a $4 \%$ formaldehyde solution. For detailed study, the worm was stained with methylene blue and then placed for a short time in alcohol to remove excess dye. After that, it was clarified in glycerol and examined under the microscopes MBS10 and Olympus CX-41. The photographs were taken by cameras Canon Digital Ixus 90 IS and Sony Cyber-shot 16.2.

\section{Results}

Scalibregmatidae Malmgren, 1867

Hiboscolex Schmarda, 1861

The live worm has a red color. The body has an approximately equal thickness throughout its length (Fig. 1A). The body length is about 25 $\mathrm{mm}$, width $1.75 \mathrm{~mm}$. Prostomium with lateral processes or horns. Eyespots reddish-brown arranged in two pairs of parallel bands along the sides of the head lobe (Fig. 1B). Most of the time the worm was burrowed in the sand and occasionally crawled over the bottom of the aquarium.

After fixation, the eyes changed color to black. The fixed polychaete is of a maggotlike shape (Fig. 1D), the length $16 \mathrm{~mm}$, width around $15^{\text {th }}$ chaetiger $1.25 \mathrm{~mm}, 43$ chaetigers. Prosto- 


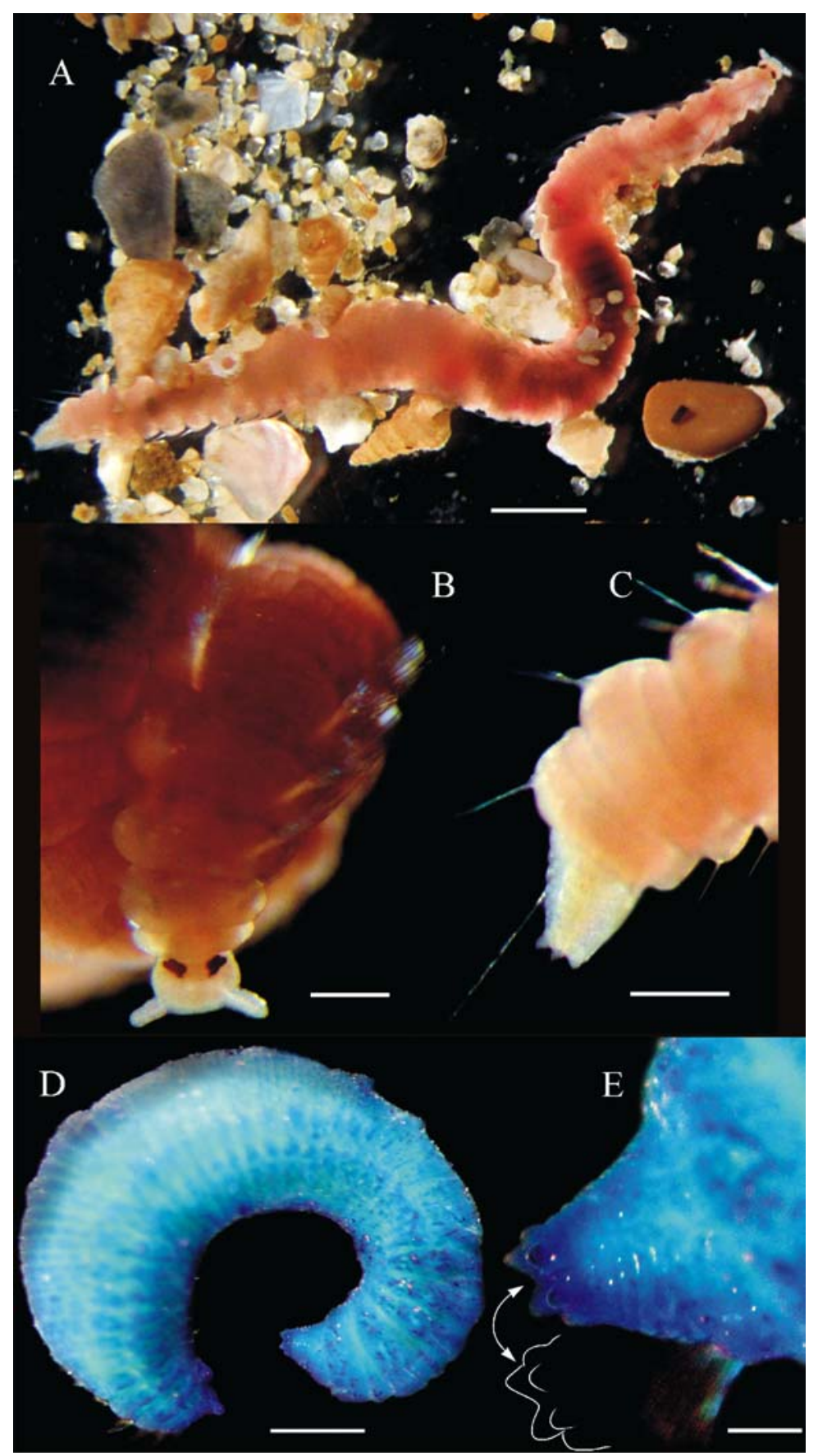

Fig. 1. Hyboscolex cf. pacificus. A - living specimen, general view; B - same, anterior end, dorsal view; $\mathrm{C}$ - same, posterior end, lateral view; D - fixed specimen, lateral view; E - same, posterior end. Scale: $\mathrm{A}-2.0 \mathrm{~mm}$; B, C, E $-0.5 \mathrm{~mm}$; D $-1.0 \mathrm{~mm}$.

Рис. 1. Hyboscolex cf. pacificus: А — живая особь, общий вид; В — то же, передний конец; С — то же, задний конец; D - фиксированная особь, латерально; Е — то же, задний конец. Масштаб: А 2,0 мм; В, C, E-0,5 мм; D - 1,0 мм. 

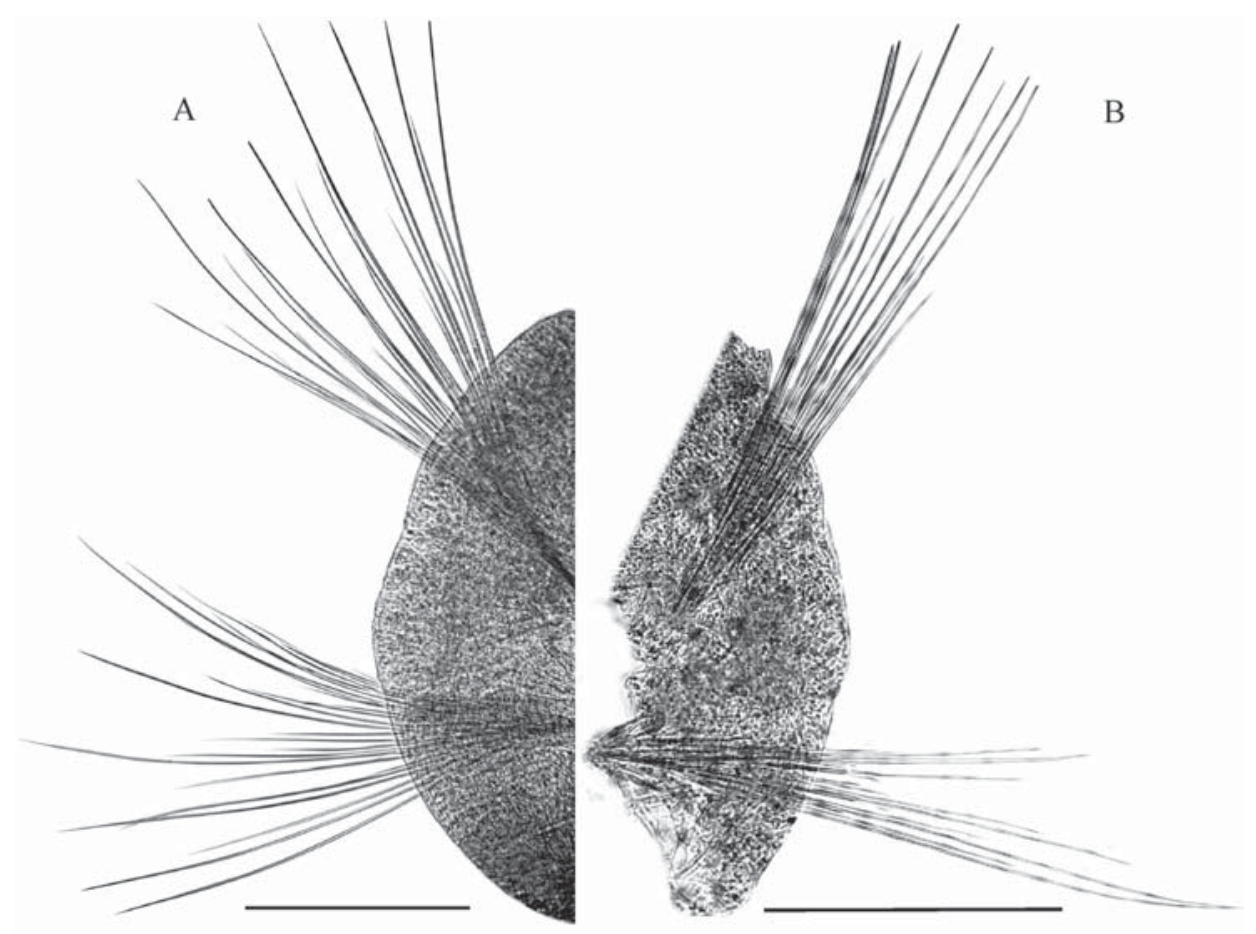

Fig. 2. Hyboscolex cf. pacificus. A - right parapodium of the chaetiger 10, anterior view; B - left parapodium of the chaetiger 36, same view. Scale: A $-280 \mu \mathrm{m}$; B $-310 \mu \mathrm{m}$.

Рис. 2. Hyboscolex cf. pacificus: А - правая параподия щетинкового сегмента 10, вид спереди; В левая параподия щетинкового сегмента 36, вид спереди. Масштаб: А $-280 \mu$ м, В $-310 \mu$ м.

mium T-shaped, partly covered with peristomium. Peristomium without chaetae, smooth, without secondary annulation. Posterior chaetigers with secondary annulation: chaetigers $2-3$ biannulate, chaetigers 4-35 triannulate. Rings divided by longitudinal grooves into many rectangular pads. The pads were more noticeable on the dorsal side. The segments 36-43 have no secondary annulation. Parapodia biramous, podial lobes reduced, in the form of small, faintly discernible knobs, without cirri. Branchiae absent (Fig. 2).

Simple, capillary chaetae of different length in noto- and neuropodia of all body chaetigers; acicular spines absent. Only capillary chaetae in chaetiger 1 (Fig. 3A). Additional row of furcate chaetae present in noto- and neuropodia in the second and all posterior chaetigers (Fig. 3B).

Furcate chaetae having two thin branches with unequal (ratio is 1.9-2.2, the average is 2) tines tapering to filamentous tips and of numerous delicate plate-like bristles on the inner margins (Fig. 3C).

Small body area anterior to pygidium narrowed, with 7-8 shortened segments, with completely reduced parapodia and solitary capillary chaetae. Pygidium with 4 small lobes (Fig. 1C, 1E). The listed morphological features are characteristic of the genus Hyboscolex Schmarda, 1861.

\section{Discussion}

The Scalibregmatidae family includes 16 genera (Read, Fauchald, 2019). According to the shape of the polychaete bodies, these genera are divided into 2 subgroups: arenicoliform (body-shape where the anterior end is expanded, narrowing posteriorly) and maggotlike (without a narrowed back) (Kudenov, Blake, 1978; 

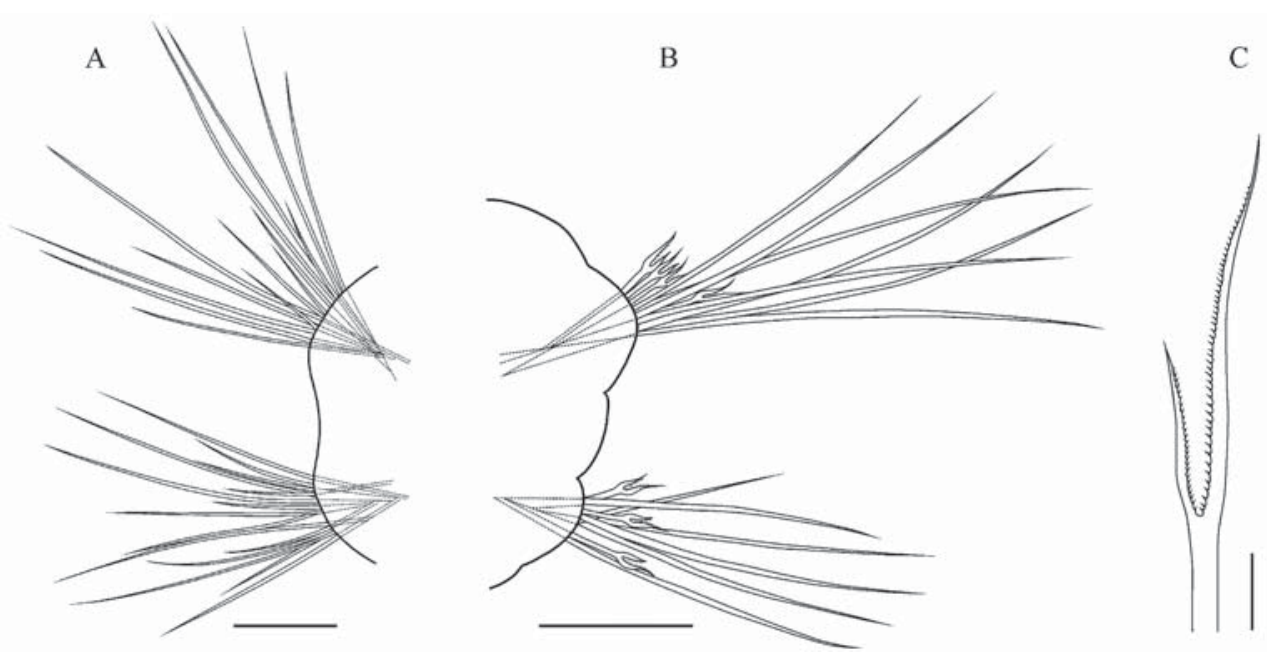

Fig. 3. Hyboscolex cf. pacificus. A - right parapodium of the chaetiger 1, anterior view; B - left parapodium of the chaetiger 31, same view; $\mathrm{C}-$ furcate chaeta. Scale: A, B $-200 \mu \mathrm{m} ; \mathrm{C}-20 \mu \mathrm{m}$. Рис. 3. Hyboscolex cf. pacificus: А - правая параподия щетинкового сегмента 1, вид спереди; В левая параподия щетинкового сегмента 31 , вид спереди; С - вильчатая щетинка. Масштаб: А, В $200 \mu \mathrm{M} ; \mathrm{C}-20 \mu \mathrm{M}$.

Blake, 1981). It is possible that the difference in the shape of the body is not so dramatic and the shape may be explained by the contraction of worms' muscles during fixation (Elder, 1973; Jirkov, 2001). The live specimen we found was rather an arenicoliform shape. However, after fixation, it took the maggotlike shape (Fig. 1A, D). For family taxonomy, important characteristics are presence/absence of (1) frontal prostomial horns, presence of branches, (2) cirri on parapodia, (3) furcate chaetae and the number of chaetiger from which they appear, and (4) cirri on pygidium. As shown in the recent studies, some of these characteristics evolve gradually during the individual development. For example, it has been shown for genus Scalibreg$m a$ Rathke, 1843, that these characteristics are fully formed in 30-segment specimens (Blake, 2015). Taking into account that the investigated specimen had 43 segments, we can assume that this was an adult one, although we did not observe its gametes.

The characteristic features of the genus $\mathrm{Hi}$ boscolex Schmarda, 1861 are the arenicoliform body, T-shaped prostomium with well-defined lateral frontal horns, presence of eyes, absence of gills and cirri on parapodia, and absence of acicular spines on the anterior segments (Schmarda, 1861; Kudenov, Blake, 1978; Blake, 1981). Our specimen had all the listed morphological features characteristic typical of this genus.

Species of Hiboscolex differ by the shape and position of the eyes, features of secondary annulations, and the presence/absence of pygidial cirri. It should be noted that $H$. pacificus (Moore, 1909) from California, like our specimen, had no anal cirri on the pygidium. However, other authors indicate that worms from the Sea of Japan may have 4 to 6 cirri on the pygidium (Uschakov, 1955; Blake, 1981), and these specimens were assigned to a subspecies H. pacificus borealis Imajima et Hartman, 1964. It was also noted that in this subspecies, the anterior chaetigers are triannulate whereas in $H$. pacificus they are biannulate (Imajima, Hartman, 1964). H. pacificus is a low-boreal amphiPacific species that is widespread along the coast of North America (the Monterey Bay, the coast of Canada), in the Sea of Japan, near the southern Kuril Islands, and at the coast of Japan and Sakhalin (Moore, 1909; Uschakov, 1955; Imajima, Hartman, 1964; Buzhinskaja, 1985). 
At the western coast of Sakhalin it was encountered $0.6-3 \mathrm{~m}$ deep on a stony seabed, at temperatures of $13.7-15.1^{\circ} \mathrm{C}$ and salinities of 33.44 $33.47 \%$. The density of aggregations was $16-$ 20 specimens $/ \mathrm{m}^{2}$ (Buzhinskaja, 1985).

We assumed that investigated specimen is most similar to H. pacificus (Moore, 1909), but tacking into account that we have not investigated this species and too interrupted range for the present time it can be identified as $H$. cf. pacificus.

Morphologicallly $H$. pacificus is similar to Hyboscolex equatorialis Blake, 1981, Hyboscolex quadricincta Kudenov, 1985 and $\mathrm{Hy}$ boscolex longiseta Schmarda, 1861. The main difference of $H$. equatorialis from $H$. pacificus is in the configuration and placement of the eyespots that are arranged in anterior posterior direction on the posterior part of the prostomium in the former. In addition, frontal horns in this species are less pronounced than in $H$. pacificus (Blake, 1981). H. quadricincta has middle segments of the body are quadriannulate rather than biannulate or triannulate, and they are distinguished by the presence of spinulose capillary chaetae instead of smooth ones as in $H$. pacificus (Kudenov, 1985). Unlike H. pacificus, $H$. longiseta have two fused pairs of large eyes and five small anal cirri, anterior segments are triannulate (Day, 1967).

In the Eastern Mediterranean, the presence of the following members of Scalibregmatidae is indicated: Asclerocheilus intermedius (SaintJoseph, 1894), A. capensis Day, 1963, Polyphysia crassa fauveli (Laubier, 1959), Scalibregma celticum Mackie, 1991, S. inflatum Rathke, 1843, Sclerocheilus minutus Grube, 1863, Hyboscolex longiseta Schmarda, 1861 (Ç nar, Da li,Kurt Şahin, 2014; Faulwetter et al., 2017). Thus our data is the first record of Scalibregmatidae from the Azov-Black Sea basin and the new species for the Mediterranean basin.

Acknowledgment. The work has been prepared within the state assignment of IMBR, state registration numbers AAAA-A18-118021350003-6 and AAAA-A18-118020890074-2. The authors are thankful to Dr. L.V. Ladygina for providing a mixture of feed microalgae.

\section{References}

Bakken T., Oug E., Kongsrud J.A. 2014. Occurrence and distribution of Pseudoscalibregma and Scalibregma (Annelida, Scalibregmatidae) in the deep Nordic Seas, with the description of Scalibregma hanseni n. sp. // Zootaxa. Vol.3753. No.2. P.101-117. http://dx.doi. org/10.11646/zootaxa.3753.2.1

Blake J.A. 1981. The Scalibregmatidae (Annelida: Polychaeta) from South America and Antarctica collected chiefly during the cruises of the R/V Anton Bruun, R/ $\mathrm{V}$ Hero and USNS Eltanin // Proceedings of the Biological Society of Washington. Vol.94. No.4. P.1131-1162.

Blake J.A. 2015. New species of Scalibregmatidae (Annelida, Polychaeta) from the East Antarctic Peninsula including a description of the ecology and post-larval development of species of Scalibregma and Oligobregma // Zootaxa. Vol.4033. No.1. P.57-93. https:// doi.org/10.11646/zootaxa.4033.1.3

Buzhinskaja G.N. 1985. [Polychaeta of the shelf of south Sakhalin and their ecology] // Issledovaniya fauny morei. Leningrad: Nauka. T.30(38). P.72-224 [in Russian].

Ç nar M.E, Da li E., Kurt Şahin G. 2014. Checklist of Annelida from the coasts of Turkey // Turkish Journal of Zoology. Vol.38. P.734-764. https://doi:10.3906/ zoo-1405-72.

Day J.H. 1967. A monograph on the Polychaeta of Southern Africa. Part 2. Sedentaria. British Museum (Natural History). London. P.459-842. http://www. biodiversitylibrary.org/bibliography/8596

Elder H.Y. 1973. Direct peristaltic progression and the functional significance of the dermal connective tissues during burrowing in the polychaete Polyphysia crassa (Oersted) // Journal of Experimental Biology. Vol.58. P.637-655. http://citeseerx.ist.psu.edu/viewdoc/download;jsessionid $=05$ F269A4CB67BCB7D 693D9EFCADC3F18? doi=10.1.1.594.552\&rep= rep $1 \&$ type $=$ pdf

Faulwetter S., Simboura N., Katsiaras N., Chatzigeorgiou G., Arvanitidis C. 2017. Polychaetes of Greece: an updated and annotated checklist // Biodiversity Data Journal. Vol.5. e20997. https://doi.org/10.3897/BDJ. 5.e20997

Imajima M., Hartman O. 1964. The polychaetous annelids of Japan // Occasional Papers of the Allan Hancock Foundation. Vol.26. No.1-2. P.1-452. http://digital library.usc.edu/cdm/ref/collection/p15799coll82/id/ 18946

Jirkov I.A. 2001. [Polychaeta of the Arctic Ocean]. Moscow: Yanus-K. 632 p. [In Russian]

Kisseleva M.I. 2004. [Polychaetes (Polychaeta) of the Black and Azov Seas]. Russian Academy of Science, Murmansk Marine Biological Institute, Kola Science Centre: Apatity. 409 p. [In Russian]

Kudenov J.D., Blake J.A., 1978: A review of the genera and species of the Scalibregmidae Polychaeta with descriptions of one new genus and three new species from Australia // Journal of Natural History. Vol.124. P. 427-444. 
Kudenov J.D. 1985. Four new species of Scalibregmatidae (Polychaeta) from the Gulf of Mexico, with comments on the familial placement of Mucibregma Fauchald and Hancock, 1981 // Proceedings of the Biological Society of Washington. Vol.98. No.2. P.332-340.

Kurt Şahin G., Çýnar M.E. 2012. A check-list of polychaete species (Annelida: Polychaeta) from the Black Sea // Journal of the Black Sea/Mediterranean Environment. Vol.18. No.1. P.10-48.

Moore J.P. 1909. Polychaetous annelids from Monterey Bay and San Diego, California. Proceedings of the Academy of Natural Sciences of Philadelphia. Vol.61. P.235-295. http://www.biodiversitylibrary.org/item/ 84740\#page/243/mode/1up

Pamungkas J. 2015. Species richness and macronutrient content of wawo worms (Polychaeta, Annelida) from Ambonese waters, Maluku, Indonesia // Biodiversity Data Journal 3: e4251. https://doi.org/10.3897/BDJ. 3.e4251
Read G., Fauchald K. (eds.). 2019. World Polychaeta database. Scalibregmatidae Malmgren, 1867. Accessed through: World Register of Marine Species at: http://www.marinespecies.org/aphia.php?p= taxdetails\&id=925 on 2018-12-21

Schmarda L.K. 1861. Turbellarien, Rotatorien und Anneliden // Neue Wirbellose Thiere: Beobachted und Gesammelt auf einer Reise um die Erdr 1853 bis 1857. Leipzig: Verlag von Wilhelm Engelmann. Bd.1. Hälfte 2. S.164. http://www.biodiversitylibrary.org/ia/ neuewirbelloseth21861 schm

Uschakov P.V. 1955. [Polychaeta of the Far Eastern Seas of the USSR] // Opredeliteli po Faune SSSR. Leningrad. Vol.56. P.1-445 [in Russian].

Responsible editor E.N. Temereva 